\title{
Transnational Lists: a False Good Idea
}

\section{Pierre Jouvenat}

It is generally thought that only transnational lists can give elections to the European Parliament a real European dimension. However, there exists another alternative which is more likely to be approved by the Council and which corresponds to the longterm federalist vision. This would be attributing all of the votes to European political parties while maintaining national quotas, national and regional constituencies.

\section{The dangers and limits of transnational lists}

Beyond theargumentsinvokedby theopponents of the idea (two-level Parliament, MEPs without any real constituents, the potential favouring of large member states), the system of two votes results in a coexistence of European and national-level constituencies that is in no manner comparable to the prevailing electoral system in German Bundestagelections.

This system would present a remarkable risk of misinterpretation by the voters. A voter could think he would vote "European" (for candidates presumed to have a European vision) in the transnational constituency only, and "national" (for candidates presumed to defend national interests in Brussels) for the vast majority of seats that are determined in the national constituencies. This could only reinforce the national character of the election, in direct contrast to the objective pursued. One has to admit that only a limited number of MEPs could be elected through transnational lists, rather than all of them. Would we want closed party lists comprising hundreds of names?

Moreover, having two lists, one featuring European and the other national parties, would perpetuate the lamentable distinction between the two. Indeed it could present them as opposites, while we should instead develop synergies and facilitate the emergence of transnational parties.

For a long-term vision of a European electoral system

No federal state has a national-level constituency, not even the tiny Switzerland.The reason is simple: a political family is normally represented by a single party, present at all levels of the federation. In accordance with the federal institutions, the parties themselves are also organised according to federal principles. The level of decision-making and the actions of the parties go hand in hand.

In a federation, no matter what the level of decision-making, all electoral activities are undertaken in local constituencies by the corresponding organs of the parties. If we believe that the EU should also, in the long term, have its own transnational partisan system, all electoral reforms should aim towards that objective, rather than doing it disservice by risking further divisions between the existing levels of the parties, as transnational lists would undoubtedly do. In the short term, to the extent that the distinction between European and national-level parties exists, in European elections it should be the European-level parties that are in the frontline throughout the entire process.

Put the European parties in the frontline for all seats In the current party system, it would be preferable to attribute all seats to European parties, for at least seven good reasons: 


\section{Borderless Debate: Reforming the EU}

1. The whole electoral process becomes a joint undertaking of the European party and its national-level partners. Europe-wide campaigns are conceived and coordinated at the European level, but implemented in a decentralised manner by national-level parties which take care of the logistics. This would reinforce synergy within politicalfamilies.

2. This way, electoral campaigning would inevitably be centred around European issues and platforms. Campaign materials and voting ballots, issued under the aegis of the European parties, would inform voters about which national party or parties have their support. This would be opposite of the system that has prevailed thus far.

3. A German citizen, for example, would not vote for CDU, but for EPP. This would be guaranteed to have a psychological effect. An excellent way to stop voting on the national governments in place, even with national-level constituencies. The voters would finally realise which issues are at stake in the election, and that for the elections to all seats.

4. The voters would vote for candidates based nearby, whom they are likely to know. Even if an MEP represented the entirety of EU citizens, as an elected official they would have to be accountable to their electorates, which could only happen in a local constituency. A limited number of well-known candidates would render preferential voting, or even a closed list system, possible. Within the system of national-level constituencies, one could explore the possibility of voting for a candidate living in another country.

5.The seats in the Parliament would be allocated according to the electoral performance of European, not national-level, parties, according to the method of "double proportionality". This would reduce, to the extent that it's feasible, the dependence of MEPs on their national-level organisations. The MEPs would henceforth be associated with a given European party rather than a multitude of national-level parties. The Parliament would gain legitimacy from this.

6. The same electoral procedure would apply to all MEPs. The homogeneity of the Parliament would be preserved.

7. Lastly, this alternative to transnational lists should meet with less resistance in the Council. National quotas are preserved and the states retain their prerogatives related to the electoral process, in the absence of the much-awaited "uniform procedure" provided for by the Treaties. Indeed, how could the member states refuse, in the context of European elections, the idea that the European-level parties should be in the frontline?

\section{What about Spitzenkandidaten?}

Of the objectives of transnational lists, only one could not be reached: the institutionalisation of the Spitzenkandidaten system. However, in the light of the position taken by the Council's legal service, we should consider this question separately and explicitly. Before that, the candidates for Commission presidency could profile themselves like they did in 2014 with known success.

In summary, making the European elections more European isn't a matter of constituency. Rather, it depends on who sends which message to the voters. The ultimate objective being the establishment of transnational federal parties, the immediate priority has to be the Europeanisation of national-level parties, which remain best placed to provide a basis for local and citizen representation in Europe: a bottomup rather than a top-down approach. 